\title{
DEKOKTA Scurulla atropurpurea TERHADAP KELENGKUNGAN TULANG BELAKANG EMBRIO IKAN ZEBRA
}

\section{Scurulla atropurpurea Decoction to Backbone of Zebra Fish Embryo}

\author{
Nour Athiroh AS \\ Universitas Islam Malang, Malang/Jawa Timur, Indonesia \\ email : nur_athiroh_mlg@yahoo.co.id \\ nour.athiroh@unisma.ac.id
}

\begin{abstract}
Toxicity study on herb Scurulla atropurpurea has done by using Zebra fish (Danio rerio) embryo. The objective of this research is to study the effect of decocta of parasitic tea leaves on theraphy dosage, MATC, and $\mathrm{LC}_{50}$ to the backbones of Zebra fish embryo. This research is done by laboratory experiment method through in vitro by using research design post randomized control group only. The animal used in this research is Zebra fish embryo less than 3 hours post fertilization after fission process is finished and embryo is entering blastula stage. Total number of sample is 80 embryos and divided into 4 groups: control group without treatment, therapy dosage group $(200 \mathrm{ug} / \mathrm{ml})$, LC50 group $(2066 \mathrm{ug} / \mathrm{ml})$ and MATC group $(237 \mathrm{ug} / \mathrm{ml})$ by decocta of parasitic tea leaves. Sample of Zebra fish embryo is putting in well-plate with 1 embryo per well. Treatment was given untill embryo at $72 \mathrm{hpf}$ at temperature $27^{\circ} \mathrm{C}$. Data taken during study is analysed using one-way ANOVA by SPSS version 16 . Treatment with therapy dosage 200, MATC 237 and LC50 of decocta of parasitic tea leaves do not cause curvature of backbone in Zebra fish embrio. It is suspected that active compound in decocta of parasitic tea leaves at all above dosage do not able to disturb the structure and function of backbone.
\end{abstract}

Key words: Decocta; parasitic tea leaves; backbone; embrio 


\section{PENDAHULUAN}

Penelitian terdahulu membuktikan bahwa benalu teh (Scurulla oortiana) mampu menurunkan kontraksi pembuluh darah arteri ekor Tikus terpisah yang diprekontraksi dengan norepinefrin (NE) pada kondisi endotel utuh secara invitro (Athiroh, 2009). Penelitian dilanjutkan secara invivo membuktikan bahwa benalu teh (Scurrula atropurpurea Bl. Danser) mampu menurunkan tekanan darah melalui perbaikan stress oksidatif dan disfungsi endotel (Athiroh et al., 2014a,b, Athiroh, 2017). Disamping itu benalu teh juga meningkatkan aktivitas Superoxide Dismutase (SOD), Nitric Oxide, Endothelial Progeniror Cell (EPC) namun menurunkan kadar Malondealdehyde (MDA) dan Circulating Endothelial Cell (CEC) pada tikus hipertensi DOCA-garam (Kawamura dan Pamudji, 2005 ; Athiroh \& Permatasari, 2012; Athiroh dan Sulistyowati, 2013 ; Mustofa et al., 2013 ; Athiroh et al., 2014a,b).

Untuk menguji keamanan benalu teh terhadap manusia dilanjutkan dengan uji toksisitas. Hasil penelitian terdahulu menunjukkan bahwa benalu teh yang dipapar secara sub kronik tidak mempengaruhi fungsi hati (Athiroh \& Sulistyowati, 2015). Pemberian benalu teh akut cenderung meningkatkan aktivitas SOD dan menurunkan kadar MDA pada Mecit (Athiroh \& Wahyuningsih, 2017). Begitu pula pada penelitian terbaru tentang uji toksisitas subkronik (selama 28 hari) pemberian benalu teh terhadap tikus betina juga tidak menunjukkan adanya perbedaan yang signifikan antara tikus kontrol dan tikus yang diberi benalu teh terhadap kadar trigliserida, kadar protein total, albumin, kreatinin, SGOT (Serum Glutamic Oxaloacetic Transaminase) serta SGPT (Serum Glutamic Pyrufic Transaminase (Munawaroh et al., 2016; Sammad et al., 2017; Prastika et al., 2017; Hikmah et al., 2017 \& Mahyan et al., 2016).

Disamping uji toksisitas terhadap tikus, benalu teh juga telah dilakukan uji toksisitas terhadap ikan zebra. Pemberian dekokta daun benalu teh dosis terapi $200 \mu \mathrm{g} / \mathrm{ml}$ tidak menyebabkan pembesaran luas area yolk sac dan pericardium embrio ikan zebra serta menurunkan denyut jantung embrio ikan zebra; (Purnamasari et al., 2016; Nugroho et al., 2016). Dosis toksik 
dekokta daun benalu teh pada ikan zebra dewasa secara akut sebesar $621,545 \mathrm{mg} / \mathrm{L}$ dan tergolong toksisitas yang ringan serta dosis toksik subkronik didapatkan hasil sebesar 4419,182 mg/L yang menyebabkan kematian 50\% ikan zebra dewasa (Hanien et al., 2016; Hasri et al, 2016). Berdasarkan hasil temuan tersebut, untuk lebih membuktikan hasil yang komprehensif, maka perlu dikaji tentang uji toksisitas benalu teh terhadap tulang belakang ikan zebra.

Tulang belakang merupakan salah satu organ yang bisa diamati pada embrio ikan zebra, chorion pada fase embrio bersifat transparan, dengan demikian memudahkan untuk dilakukan pengamatan terhadap tulang belakang (Leischke8 \& Currie, 2007; Detrich et al., 2009; Langgheinrich, 2003). Tujuan penelitian ini untuk mengetahui pengaruh dekokta benalu teh (Scurulla atropurpurea) pada dosis terapi, MATC, dan $\mathrm{LC}_{50}$ terhadap kelengkungan tulang belakang embrio ikan zebra.

\section{METODE PENELITIAN}

\section{a. Waktu dan Tempat Penelitian}

Penelitian dilaksanakan di Laboratorium Terpadu Fakultas Kedokteran Universitas Islam Malang dari bulan November 2015 sampai bulan April 2016, Fakultas Perikanan dan Kelautan Universitas Muhammadiyah Malang dan Balai Meteria Medika Batu.

\section{b. Bahan dan Alat}

Tetramin, kultur artemia, alkohol, alumunium foil, embryonic medium (disimpan dalam refrigator $4-8^{\circ} \mathrm{C}$ ) stok $10 \mathrm{x}$, dengan komposisi : MgSO4: 0,815 g, NaCL: 5 g, KCl: 0,15 g, $\mathrm{CaCl}_{2} \cdot 2 \mathrm{H}_{2} \mathrm{O}: 0,26 \mathrm{~g}$, Aquades: $500 \mathrm{ml}$.

Inkubator dengan suhu $27^{\circ} \mathrm{c}$, Dispossible pipette, 24-Well plate, aquarium $60 \mathrm{~cm} \times 30 \mathrm{~cm} \times 35 \mathrm{~cm}$, purified water, thermometer, heater, panci dekokta, $\mathrm{pH}$ indicator, kompor listrik, tabung ukur, wadah tempat penyimpanan, timbangan digital, batang pengaduk, beker glass $300 \mathrm{ml}$, aquades, corong gelas, vacum, erlenmeyer. 


\section{c. Metode Penelitian}

\section{- Persiapan hewan coba}

Hewan coba yang digunakan adalah embrio ikan zebra $<3$ jam post fertilisasi pada saat proses pembelahan telah selesai dan embrio masuk pada periode blastula.

\section{- Aklimatatisasi ikan zebra}

Embrio ikan zebra (Danio rerio) berasal dari pemijahan ikan zebra yang berumur 4 bulan, terlebih dahulu diaklimatisasi selama 1 minggu di Laboratorium Terpadu Fakultas Kedokteran Universitas Malang. Ikan zebra diperoleh dari petani ikan di desa Wajak lor, Tulungagung, Jawa Timur telah disertifikasi di Fakultas Perikanan dan Kelautan Universitas Muhammadiyah Malang.

- Preparasi daun benalu teh

Daun Benalu teh diperoleh dari Blitar yang telah disertifikasi oleh UPT Balai Materia Medika, Kota Batu, Jawa Timur, Indonesia. Daun benalu teh dikeringkan dengan cara dioven pada suhu $40-60^{\circ} \mathrm{C}$, kemudian digiling hingga menjadi serbuk (simplisia) di UPT Balai Materia Medika, Kota Batu.

Dekokta daun benalu teh dibuat dengan cara merebus masing-masing simplisia sebesar $200 \mathrm{mg}$, $237 \mathrm{mg}$, dan 2066 mg dalam $500 \mathrm{ml}$ aquades pada suhu $90^{\circ} \mathrm{C}$ selama 30 menit. Pada dosis terapi $200 \mu \mathrm{g} / \mathrm{ml}$, dekokta daun benalu teh diberikan dengan cara memasukkan 0,5 ml dekokta ditambah 0,5 ml cairan embrionik. Pada dosis MATC $237 \mu \mathrm{g} / \mathrm{ml}$, dekokta daun benalu teh diberikan dengan dengan cara memasukkan 0,5 ml dekokta ditambah $0,5 \mathrm{ml}$ cairan embrionik. Sedangkan pada dosis $\mathrm{LC}_{50} 2066 \mu \mathrm{g} / \mathrm{ml}$ dekokta daun benalu teh diberikan dengan cara memasukkan 0,5 ml dekokta ditambah 0,5 ml cairan embrionik.

- Rancangan Penelitian

Rancangan penelitian dengan metode eksperimental laboratorium menggunakan post test only control group 
design. Jumlah total sampel sebanyak 80 embrio ikan zebra yang terbagi dalam 4 kelompok yaitu kelompok kontrol, kelompok dosis terapi (200ug/ml), kelompok LC $_{50}(2066$ $\mathrm{ug} / \mathrm{ml}$ ), dan kelompok MATC (237 ug/ml) dekokta daun benalu teh. Sampel embrio ikan zebra diletakkan pada wellplate dengan 1 embrio per well. Perlakuan diberikan sampai embrio berusia $72 \mathrm{hpf}$ dan suhu inkubator dipertahankan pada $27^{\circ} \mathrm{C}$. Pengukuran kelengkungan tulang belakang dilakukan menggunakan metode Wang et al., (2019)

\section{- Laik Etik}

Penelitian ini telah mendapatkan persetujuan dari Komisi Etik Penelitian Fakultas Kedokteran Universitas Brawijaya nomor :369/EC/ KEPK/06/2015.

\section{- Analisis Data}

Data hasil penelitian dianalisis dengan ANOVA dan dilanjutkan dengan uji Least Significant Difference (LSD) menggunakan software SPSS versi 16.

\section{HASIL DAN PEMBAHASAN}

Hasil uji normalitas $\mathrm{p}>0.05$ didapatkan bahwa sebaran datanya normal. Kemudian dilakukan dengan uji One-way ANOVA (Analysis of Variance). Hasil uji One-way ANOVA diperoleh bahwa nilai $\mathrm{p}=0.000(\mathrm{p}<005)$. Selanjutnya dilanjutkan dengan Post hoc test untuk mengetahui kelompok yang mempunyai perbedaan bermakna, menggunakan uji (LSD). 
Tabel 1.

Karakteristik sampel

\begin{tabular}{ccccc}
\hline Perlakuan & $\begin{array}{c}\text { Usia } \\
\text { (hpf) }\end{array}$ & $\begin{array}{c}\text { Total } \\
\text { embrio }\end{array}$ & $\begin{array}{c}\text { Pajanan } \\
\text { (hpf) }\end{array}$ & $\begin{array}{l}\text { Dosis DDBT } \\
\text { (ug/ml) }\end{array}$ \\
\hline KN & 5,25 & 20 & 72 & - \\
P1 & 5.25 & 20 & 72 & 200 \\
P2 & 5,25 & 20 & 72 & 2066 \\
P3 & 5,25 & 20 & 72 & 237 \\
\hline
\end{tabular}

Keterangan:

$\begin{array}{ll}\text { KN } & \text { : Kontrol (Medium Embrionik) } \\ \text { P1 } & \text { : Perlakuan dosis terapi 200 } \\ \text { P2 } & \text { : Perlakuan dosis MATC 237 } \\ \text { P3 } & \text { : Perlakuan dosis LC50 } 2066\end{array}$

Tabel 2.

Data kelengkungan tulang belakang embrio ikan zebra

\begin{tabular}{ccccc}
\hline N & \multicolumn{4}{c}{ Perlakuan } \\
& Kontrol & LC50 & MATC & Terapi \\
\hline 1 & 166890,5 & 164793,5 & 166326,5 & 166820,0 \\
2 & 162869,5 & 159886,5 & 161729,0 & 170694,0 \\
3 & 163863,5 & 165462,0 & 153212,0 & 164712,0 \\
4 & 167214,5 & 163656,0 & 162061,0 & 167552,5 \\
5 & 160257,5 & 177150,5 & 175388,0 & 170137,5 \\
6 & 163402,5 & 163222,0 & 172442,0 & 165661,0 \\
7 & 172295,0 & 167462,0 & 165127,5 & 170626,0 \\
8 & 164178,5 & 168986,0 & 167079,0 & 157595,5 \\
9 & 161441,5 & 162408,5 & 165168,5 & 168499,0 \\
10 & 159804,5 & 159959,0 & 173734,5 & 161028,0 \\
Total & 1642217,5 & 1652986,0 & 1662268,0 & 1663325,5 \\
Mean \pm & 164221,8 & 165298,6 & 166226,8 & 166332,6 \\
SD & $\pm 3754,2$ & $\pm 5079,3$ & $\pm 6574,0$ & $\pm 4293,5$ \\
\hline
\end{tabular}

Berdasarkan tabel 1 , terlihat bahwa rata-rata area tulang belakang tertinggi sebesar $166.332,6^{\circ}$ terdapat pada perlakuan 
Terapi. Sedangkan rata-rata area tulang belakang terendah sebesar $164.221,8$ terdapat pada kontrol. Berdasarkan nilai rata-rata tersebut dapat dikatakan bahwa pemberian perlakuan mampu meningkatkan rata-rata area tulang belakang.

Selanjutnya dilakukan uji One-way ANOVA untuk mengetahui apakah terdapat perbedaan rata-rata area tulang belakang antar masing-masing perlakuan. Data area tulang belakang pada masing-masing perlakuan memiliki nilai signifikansi hasil analisis yang lebih besar dari taraf nyata 5\% sehingga disimpulkan data hasil penelitian tersebut berdistribusi normal. Kelengkungan tulang belakang yang terdiri dari 4 perlakuan memiliki ragam yang homogen karena nilai signifikansi (p-value) yang diperoleh dari hasil analisis lebih besar dari 0,05. Hasil uji LSD (Least Square Difference) menunjukkan bahwa ratarata area tulang belakang tertinggi terdapat pada perlakuan terapi. Sedangkan rata-rata area tulang belakang terendah terdapat pada kontrol. Kedua perlakuan ini tidak berbeda signifikan dengan perlakuan yang lain, karena hasil pengujian LSD menunjukkan tidak adanya perbedaan notasi pada masing-masing perlakuan. Hal ini menunjukkan bahwa semua perlakuan memiliki rata-rata area tulang belakang yang tidak berbeda signifikan.

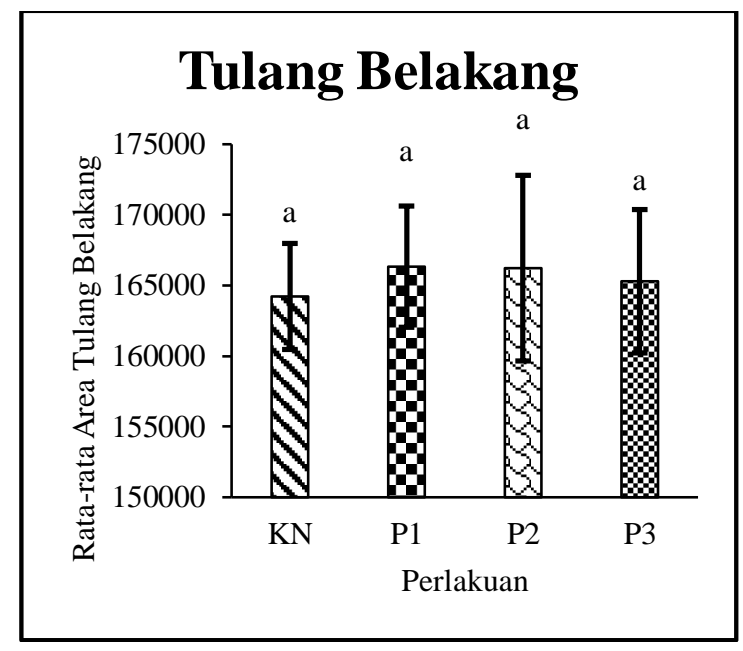

Gambar 1. Histogram Rerata kelengkungan tulang belakang embrio ikan Zebra. 


\section{Keterangan:}

KN : Kontrol Normal (medium embrionik)

P1 : Perlakuan dosis terapi 200

P2 : Perlakuan dosis MATC 237

P3 : Perlakuan dosis LC 502066

Notasi menunjukkan perbedaan yang tidak signifikan $(\mathrm{p}>0.05)$

Tulang belakang embrio ikan zebra mulai terbentuk pada usia 5,25hpf (hour pass fertilization) yang merupakan periode gastrula. Pada periode ini awal pergerakan epiboli sampai akhir terjadi dan celah blastoderm mulai menutup. Usia 10,5hpf (periode segmentasi) segmen ekor dan tulang belakang ikan zebra mulai terlihat, namun segmen badan masih belum bisa dibedakan. Selanjutnya pada usia $24 h p f$ atau saat embrio ikan zebra memasuki periode pharingula terjadi pelepasan ekor dari yolk salk terlihat gerakan spontan dan mulai terjadi pigmentasi. Kemudian pada usia $72 h p f$ (periode penetasan) tulang belakang sudah dapat diamati dengan jelas (Kimmel, 1995).

Pemberian dekokta daun benalu teh dosis terapi $200 \mathrm{ug} / \mathrm{ml}$, dosis MATC 237ug/ml, dan dosis $\mathrm{LC}_{50}$ 2066ug/ml tidak menyebabkan kelengkungan tulang belakang. Hal ini diduga kandungan senyawa zat aktif (rutin dan quersetin) benalu teh pada ketiga dosis tersebut tidak mamapu mengganggu struktur dan fungsi tulang belakang.

Berdasarkan penelitian Ainia (2015) pemberian dekokta Kumis kucing (Orthosiphon stamineus, Benth) dosis 381ug/ml dan $870 \mathrm{ug} / \mathrm{ml}$ menyebabkan kelengkungan tulang belakang ikan zebra. Hal ini dikarenakan senyawa flavonoid pada herbal ini dapat menginduksi keluarnya sitokin inflamasi seperti IL-1, IL-6, dan TNF- $\alpha$ yang dapat menstimulasi osteoklas sehingga menyebabkan resorbsi tulang dan mengakibatkan terjadinya osteoporosis serta kelengkungan tulang belakang secara abnormal.

\section{KESIMPULAN}

Pemberian dekokta daun benalu teh dosis terapi $200 \mathrm{ug} / \mathrm{ml}$, dosis MATC 237ug/ml, dan dosis $\mathrm{LC}_{50}$ 2066ug/ml tidak menyebabkan kelengkungan tulang belakang. 


\section{UCAPAN TERIMA KASIH}

Peneliti mengucapkan terimakasih kepada Kementerian Riset dan Teknologi Pendidikan Tinggi (Kemenristek DIKTI) Strategis Nasional (STRANAS), sesuai dengan Surat Perjanjian Pelaksanaan Penugasan Hibah Nomor: 022/SP2H/K2/KM/2017, tanggal 04 Mei 2017.

\section{DAFTAR PUSTAKA}

Ainia, H.N., Heru, A, Fadli, Z. (2015). Uji toksisitas akut dekokta orthosiphon stamineus, Benth terhadap daya tetas dan malformasi organ embrio Danio rerio. Jurnal Kedokteran Komunitas. Fakultas Kedokteran Universitas Islam Malang.

Athiroh, N. (2009a). Kontraktilitas pembuluh darah arteri ekor tikus terpisah dengan atau tanpa endotel setelah pemberian ekstrak Scurulla oortiana (benalu teh). Jurnal Berkala Hayati. No.3D. ISSN: 0852-6834.

Athiroh, N. (2009b). Pemaparan Scurulla oortiana (benalu teh) dan Macrosolen javanus (benalu jambu mawar) setelah stimulasi listrik terhadap kontraksi pembuluh darah arteri ekor tikus. Prosiding Bioteknologi. Seminar Nasional Biologi XX dan Kongres PBI XIV. Malang: 58-63. ISBN 978602-95471-0-8

Athiroh, N. (2010). Effect of Scurulla oortiana and Macrosolen Javanus for vasodilator of blood vessel. Prosiding. SEMNAS Basic Science VII UB. Malang : 271-277. ISBN: 978-60296393-0-8.

Athiroh, N and N. Permatasari. (2012). Mechanism of tea mistletoe action on blood vessels. Medical Journal Brawijaya, 27 (1), $1-4$. 
Athiroh, N and E. Sulistyowati. (2013). Scurrula atropurpurea increases Nitric Oxide and decreases malondialdehyde in hypertensive rats. Univ Med, 32, 44-50.

Athiroh N., N. Permatasari, D. Sargowo, \& M. A. Widodo. (2014ª). Antioxidative and blood pressure-lowering effects from Scurrula atropurpurea on DOCA-salt hypertensive rats. Biomarkers and Genomic Medicine Journal, 1, 32-36.

Athiroh N., N. Permatasari, D. Sargowo, and M.A. Widodo. (2014b). Effect of Scurrula atropurpurea on nitric oxide, endothelial damage, and endothelial progenitor cells of DOCA-salt hypertensive rats. Iran J Basic Med Sci, 17, 622-625.

Athiroh, N., E. Sulistyowati. (2015). Extract of Scurrula atropurpurea (Bl.) Dans sub chronic exposure on wistar rat liver. AENSI Journals Advances in Environmental Biology, 9(23), 245-250.

Athiroh, N. \& Wahyuningsih, D. (2017). Study of superoxide dismutase and malondialdehyde concentrations in mice after administration of methanolic extract of Scurrula atropurpurea (Bl.). Jurnal Kedokteran Hewan, 11 (1). 1922.

Athiroh, N. (2017). Monograf. Benalu teh dan hipertensi. Intelligensia Media. Malang Indonesia.

Badan Pengawas Obat dan Makanan Republik Indonesia. Peraturan Kepala Badan Pengawas Obat Dan Makanan Republik Indonesia Nomor 7 Tahun (2014) Tentang Pedoman Uji Toksisitas Nonklinik Secara In Vivo.

de Moura, R.S., A.F. Emiliano, L.C.R. Marins de Carvalho, L.C.R. Souza, D.C. Guedes, T. Tano, A.C. Resende. (2005). Antihypertensive and endothelium-dependent vasodilator effects of Alpinia zerumbet, a medicinal plant. J Car diovasc PharmacolTM, 46, 288-294. 
Detrich, H.W., Westerfield, M., Zon, L.I. (2009). Essential zebrafish method : Genetics and genomics. Elseivier. 1st edition. U.K

Eno, A.E., U.E. Ibokette, Ofem, F.B. Uoh, E. Nkanu, N. Azah, J.O. Ibu. (2004). The effects of a negerian species of Viscum album (mistletoe) leaf extraction on the blood pressure of normotensive and DOCA_induced hypertensive rats. Nigerian Journal of Physiological Sci, 19 (1-2), 33-38.

Halliwell, B. and M.C. Gutteridge. (2010). Role of free radicals and catalytic metal ions in human disease. Oxford. Clarendon Press.

Hanien, D.N., Firmansyah, M., Athiroh, N. (2016). Nilai LC 50 ikan zebra dewasa yang dipapar oleh dekokta daun benalu teh (Scurulla atropurpurea Bl.Danser) secara akut dan subkronik. Jurnal Bio Komplementer Medicine, 3 (1), 65-70.

Hasri, Y.U., Firmansyah, M., Athiroh, N. (2016). Nilai LC $\mathrm{C}_{\mathrm{C} 0}$ embrio dan larva ikan zebra (Danio rerio) yang dipapar dekokta daun benalu teh (Scurrula atropurpurea Bl. dans.) secara akut. Jurnal Bio Komplementer Medicine, 3 (1), 59-64.

Hikmah, U., Athiroh,, N., Santoso, H. (2017). Kajian sub kronik ekstrak metanolik Scurrula atropurpurea (Bl.) Dans. terhadap serum glutamic oxaloacetic transaminase tikus wistar betina. e-Jurnal IImiah BIOSAINTROPIS, 2 (2), 30-35.

Jiménez, R., R. López-Sepúlveda , M. Kadmiri , M. Romero , R. Vera , M. Sánchez , F. Vargas , F. O'Valle , A. Zarzuelo , M. Dueñas , C. Santos-Buelga, J. Duarte. (2007). Polyphenols restore endothelial function in DOCA-salt hypertension: role of endothelin-1 and NADPH oxidase. Free Radic Biol Me,. 43(3), 462-73.

Kawamura, E., \& Pamudji. (2005). Pharmaceutical composition containing powder or extract of a paraite plant of the 
loranthaceae family. European Patent Aplication. EP 1591 126 A2.

Langgheinrich, U. (2003). Bioassay. Vol. 25. 904-912.

Leischke, G.J., \& Currie, P.D. (2007). Animal models for human desease: Zebrafish swim into view. Nat Pub Group. 8 : 353367.

Mahyan, A., Athiroh, N., Santoso, H. (2016). Paparan 28 hari ekstrak metanolik Scurrula atropurpurea terhadap kadar SGPT tikus betina. e-Jurnal Ilmiah BIOSAINTROPIS, 2(1), 53-58.

Munawaroh, N.S., Athiroh, N., Santoso, H. (2016). Kajian ekstrak metanolik Scurrula atropurpurea (Bl.) Dans. terhadap kadar trigliserida pada tikus wistar betina. e-Jurnal Ilmiah BIOSAINTROPIS, 2(1), 59-64.

Murphy, KJ., A.K. Chronopolous, I. Singh, M.A. Francis, H. Moriarty, M.J. Pike, A.H. Turner, N.J. Mann, and J. Sinclair. (2003). Dietary flavanols and procyanidin oligomers from cocoa (Theobroma cacao) inhibit platelet function. American Journal of Clinical Nutrition, 77 (6), 1466-1473.

Mustofa, B., A. Hayati, dan N. Athiroh. (2013). Peran ekstrak metanolik benalu teh terhadap perbaikan stress oksidatif melalui peningkatan SOD pada tikus hipertensi. Jurnal Ilmiah Bio saintropis, 1 (2), 1-4.

Nugroho, R.T., Herbani, M., Athiroh, N. (2016). Efek dekokta daun benalu teh (Scurrula atropurpurea BL Danser) dosis terapi, MATC, dan $\mathrm{LC}_{50}$ terhadap denyut jantung dan daya tetas embrio ikan zebra (Danio rerio). Jurnal Bio Komplementer Medicine, 3 (1), 51-58.

Ortiz, P.A., and J.L. Garvin. (2001). Intrarenal transport and vasoactive substances in hypertension. Hypertension, 38, 621-624. 
Purnamasari, D., Herbani, M., Athiroh, N. (2016). Efek dekokta daun benalu teh (Scurrula atropurpurea Bl. Dans) dosis terapi, MATC, dan Lc50 terhadap luas area yolk sac serta pericardium embrio ikan zebra (Danio rerio). Jurnal Bio Komplementer Medicine, 3 (1), 167-173.

Prastika, N.I., Athiroh, N., Santoso, H. (2017). Pengaruh pemberian sub kronik ekstrak metanolik Scurrula atropurpurea (Bl.) Dans. terhadap kadat kreatinin tikus wistar. e-Jurnal IImiah BIOSAINTROPIS, 2(2), 42-48.

Redon, J.M., M.R. Oliva, C. Tormos, V. Giner, J. Chaves, A. Iradi, G.T. Saez. (2003). Antioxidant activities and oxidative sress byproducts in human hypertension. Journal of The American Heart Association, 41, 1096-1101.

Sammad, F.A.H., Athiroh, N., Santoso, H. (2017). Pemberian ekstrak metanolik Scurrula atropurpurea (Bl.) Dans. secara sub kronik terhadap protein total dan albumin tikus betina. $e$ Jurnal Ilmiah BIOSAINTROPIS, 2(2), 49-54.

Vaziri, N.D., and B. Rodriguez-Iturbe. 2006. Mechanisms of Disease: Oxidative Stress and Inflammation in The Pathogenesis of Hypertension. Nat Clin Pract Nephrol, 282-593.

Wang, S., Kechun Liu, Ximing Wang, Qiuxia He, and Xiqiang Chen. (2010). Toxic effect of celastrol on embryonic development of zebra fish (Danio rerio). Biology Institute of Shandong Academy of Sciences, Jinan 250014, Shandong, China. 